\title{
Academic Libraries in For-Profit Schools of Higher Education
}

\section{Jinnie Y. Davis, Mignon Adams, and Larry Hardesty}

\begin{abstract}
For-profit schools constitute the fastest-growing sector of higher education institutions in the United States. ${ }^{1}$ Yet accompanying the phenomenal growth of these proprietary colleges and universities has been considerable controversy over the role that the profit motive should play in higher education. ${ }^{2}$ The literature of higher education contains increasingly more works about proprietary schools. The library literature, however, offers little in this arena. Through this article, the authors seek to introduce the library readership to U.S. for-profit colleges and universities. We summarize their history and their characteristics, and we explore reasons for their success and present areas in which these schools appear to excel. With regard to their library services and resources, we focus on issues of concern based specifically on our experience with academic libraries in proprietary schools operating in the state of Ohio. Finally, we suggest ways in which these for-profit institutions can address the challenges faced by their libraries.
\end{abstract}

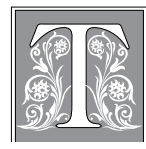

he authors became immersed in the for-profit world as library consultants for the Ohio Board of Regents. In that state, the Regents' office is responsible for the authorization of all private higher education institutions as well as new programs offered by those schools. The review process involves a site visit by a team of content experts, typically including a library consultant. The team assesses an institution to ensure that it meets Regents' standards as stated in Rule 3333-1-08 of the Ohio Administrative Code. In the 1990s, many large for-profit university systems sought authorization to offer degree programs, often online, in Ohio. In 2008, a state legislative mandate required Regents' authorization for the first time for all Ohio career colleges seeking eligibility for their students to receive certain state grants. The Regents staff then began a year-long undertaking to integrate participating career colleges into the review process. As part of these developments, the authors collectively have reviewed 30 for-profit institutions seeking authorization in Ohio. ${ }^{3}$

\section{Literature Review}

Most research on for-profit colleges and universities in the United States comes from the literature of higher education and from state and federal government reports. Early on, Lee and Merisotis

Jinnie Y. Davis is Librarian Emerita at the North Carolina State University Libraries; e-mail:jinnie_davis@ncsu. edu. Mignon Adams is Professor Emeritus at the University of the Sciences in Philadelphia; e-mail:m.adams@ usp.edu. Larry Hardesty is retired library director at Austin College; e-mail: ebony51@frontiernet.net. Davis made a presentation on this topic at the 5th Kaser Lecture at Indiana University on April 1, 2010. The authors extend our gratitude for comments on an early version of the manuscript from Larry Cooperman, Everglades University; William Crowe, University of Kansas; Stephanie Davidson and Shane DeGarmo, The Ohio Board of Regents; Marc Gartler, Madison Public Library. (C) Jinnie Y. Davis, Mignon Adams, and Larry Hardesty 
sought to shed light on this emerging but largely ignored sector that was outside the bounds of traditional higher education and for which published data were lacking. ${ }^{4}$ They discuss the development of proprietary schools and their role in higher education, curricula and student characteristics, and educational outcomes. More recently, Zamani-Gallaher updated (to 2004) the literature on U.S. proprietary schools in a comprehensive article. ${ }^{5}$ She covers their history and characteristics and discusses implications for educational leadership, policy, and institutional research. Among the key monographs that address this sector are Ruch's Higher Ed, Inc. (2001), ${ }^{6}$ Berg's Lessons from the Edge (2005), ${ }^{7}$ Breneman, Pusser, and Turner's Earnings from Learning (2006), ${ }^{8}$ and Donoghue's The Last Professors (2008). ${ }^{9}$

Because many for-profit institutions are career schools offering two-year programs, their students and curricula tend to be similar to those of traditional community colleges. The growing competition posed by the for-profits has generated considerable attention in the community college literature. Clowes and Hawthorne (1995) explored whether these two types of schools will eventually converge, or if their fundamental differences (of mission and so on) will prevent any true merging. ${ }^{10}$ Bailey, Badway, and Gumport (2001) produced a detailed report on the relationship of for-profit institutions to community colleges. ${ }^{11}$ More recently, Outcalt and Schirmer updated the literature on that relationship. ${ }^{12}$

The higher education literature also examines whether proprietary schools are succeeding, according to various measures of outcomes and results. Proponents claim that "proprietary schools have become a cost-effective way to deliver education to a community of students that traditional colleges have not served well,..."13 For example, Kinser agrees that for-profit institutions do increase access to higher education for students not served by traditional academia. ${ }^{14} \mathrm{He}$ finds, however, that this access comes at a cost, including the expense incurred by the students, the limited scope of the programs, and the limited capacity of most proprietary schools.

A study by the Imagine America Foundation, a nonprofit organization that provides student scholarships and faculty development for career colleges, related that for-profit students have comparable and often higher retention and graduation rates than those at other institutions. ${ }^{15}$ Reacting to its findings, David S. Baime, vice president for government relations at the American Association of Community Colleges, guardedly stated: "We have a very hard time squaring these numbers with the fact that for-profit students have the highest federal student-loan default rates, regrettably also coupled with shockingly high debt burdens that dwarf those of any sector."16

Proprietary schools are clear that the value-added element of their educational offerings is the assurance that graduates will be better able to obtain employment and will have greater earning power. ${ }^{17}$ This is a powerful draw for students whose primary goal is to find a job, particularly in times when the lesser educated may have been laid off or unable to compete successfully for employment. A 2010 New York Times article notes that the for-profits are benefiting from the recent recession. The author cautions that, although supporters claim they are preparing individuals for careers, "[c]ritics say many schools exaggerate the value of their degree programs, selling young people on dreams of middle-class wages while setting them up for default on untenable debts, low-wage work and a struggle to avoid poverty." 18

Investigating this criticism, ZamaniGallaher reviewed studies on whether attendance at a for-profit institution results in greater job opportunities. She concludes that "[ $\mathrm{t}]$ he impact of proprietary attendance on educational outcomes and economic mobility is still fairly ambiguous. Despite the fact that private, forprofit institutions receive some favorable marks, the issues that are repeatedly questioned-among them, quality of programs, 
student satisfaction, and impact on student outcomes, continue to be topics of concern requiring further investigation." ${ }^{19}$ Kinser notes the paucity of data on the transition of students to the workforce and concludes that, " $[w]$ ithout independent data on outcomes, it is difficult to assess the for-profit sector's success in this area." 20

The quality of education at for-profits attracts attention because of the high costs at many proprietary institutions and the amount of monies that state and federal governments provide to their students. According to Kinser, "[q]uality and efficacy remain a concern, especially considering how much aid is in the form of loans that students must repay after graduation..."21

Much of the latest news relating to proprietary schools can be found in such sources as The Chronicle of Higher Education, online newspapers, and ERIC reports. ${ }^{22}$ Current media attention focuses on the controversy surrounding the amount of federal monies received by proprietary schools, while many of their students are saddled with tremendous debt burdens. According to Kinser, "[w]ithout the framework of federal grants and loans, the for-profit sector in its current formulation would be untenable as a business and fail as an access path." 23

The academic library is rarely mentioned in the literature on for-profit institutions, either in the higher education or library literature. The prevailing attitude toward the library in a for-profit institution is that "however important libraries may be, they are expensive and unprofitable, they occupy what operations managers view as unproductive space, and therefore they reduce profit margins." ${ }^{24}$ Kirp, writing about the University of Phoenix, contrasts the traditional and the for-profit views of libraries: "[W]hile to academics libraries are sacred places, the Phoenix administrators contended that access to a nearby library was sufficient..." ${ }^{25}$ The authors were unable to find any published research on academic libraries in proprietary schools. As with the institutions themselves, comprehensive sources of comparative or longitudinal data on their libraries are lacking.

\section{History and Characteristics of Proprietary Schools}

A brief overview ${ }^{26}$ of the development of proprietary schools in the United States is useful for an understanding of this sector. Their history in this country can be traced back to the 17th century when the Dutch established private schools to teach practical skills such as bookkeeping and penmanship to an uneducated populace. ${ }^{27}$

Over the years, the number of these private institutions grew, particularly as business schools that addressed the practical training lacking in a classical education. ${ }^{28}$ Immediately after World War II, new technological demands and the funding available through the G.I. Bill led to a substantial increase in private, forprofit schools offering trade and technical training. ${ }^{29}$

Today's for-profit institutions fall primarily into three categories: those offering a certificate with less than two years of vocational or technical studies; two-year schools that award associate's degrees and certificates; and programs that also offer four-year bachelor's programs and, increasingly, master's and doctoral degrees. This article focuses on the last two categories. ${ }^{30}$

Proprietary schools range greatly in the scale of their operations. "Of the roughly 3,000 for-profit institutions, 40 percent are now owned by one of 13 large, publicly traded companies." ${ }^{31}$ Much of the media attention targets this type of university system, which primarily consists of schools whose offerings include advanced degrees such as an MBA or a doctorate in education. They are also more likely to offer online degree programs. Typical programs at two-year career schools reflect their original business orientation (for example, an associate's degree as an administrative assistant) or focus on specialized fields such as art and design. Recent offerings concentrate on programs in the applied sciences, such as computer science and health care. 
The exponential growth in enrollment at for-profits, which usually follow openenrollment practice, has been remarkable: "[s\}ix years ago, there were almost three times as many students enrolled in private nonprofit colleges as there were at forprofit institutions. By 2008-9, that ratio had slipped to about 2 to $1 .^{\prime \prime 32}$ A recent article reports that "[e]nrollment in the country's nearly 3,000 career colleges has grown far faster than in the rest of higher education-by an average of 9 percent per year over the past 30 years, compared with only 1.5 percent per year for all institutions. For-profit universities now educate about 7 percent of the nation's roughly 19 million students who enroll at degreegranting institutions each fall." ${ }^{33}$ This figure translates into well over a million students, not an inconsequential number.

For many years, those in traditional colleges and universities tended to ignore their for-profit counterparts. With the growth in student enrollment, the for-profit sector drew greater attention, although most in traditional higher education tended to view the for-profits with suspicion. In 1998, the president of Columbia University's Teachers College contended that " $[w]$ ithin higher education, 'proprietary' is still a dirty word." ${ }^{34}$ Stories of abuses reported in the press, such as lawsuits over illegal recruitment practices, fueled these suspicions. A recent Government Accountability Office study found evidence of fraud, deception, or questionable marketing practices when undercover investigators posed as applicants at 15 for-profit colleges around the nation. ${ }^{35}$

Just as administrators at proprietary schools believe their sector is overlooked by traditional higher education, librarians who work in for-profit institutions often feel slighted by their colleagues from the not-for-profits. Communications on ACRL's Librarians in For-Profit Educational Institutions (LFPEI) listserv, for example, include complaints about the lack of respect accorded them by academic librarians in traditional institutions.
We want to be clear that the institutions covered in this article are not diploma mills that will award a student an essentially worthless "degree" based on few or no academic requirements, bestowed upon receipt of a designated fee. Although proprietary schools operated with little national oversight for years, the 1992 reauthorization of the Higher Education Act imposed federal regulations that brought them into closer compliance with standards of the traditional institutions. Smaller career schools that focus on vocational or technical training are usually accredited by national associations such as the Accrediting Commission of Career Schools and Colleges (ACCSC) or the Accrediting Council for Independent Colleges and Schools (ACICS). Four-year for-profits now increasingly seek traditional accreditation by regional agencies approved by the U.S. Department of Education.

Who attends for-profit schools? Several researchers have examined the characteristics of students in proprietary schools. A recent report described them as older than the traditional-aged college student and more likely to be members of a minority. They are less likely to complete a college program, and their parents have limited or no college education. They have more social risk factors such as "delayed enrollment (from high school to postsecondary school), not having a high school diploma, enrolling part-time rather than full-time, being financially independent, having dependent children, being a single parent, and working full-time while enrolled." ${ }^{36}$ The for-profits' outreach to this population is often cited as one of its successes. Berg, for examples, argues that proprietary schools are able to make profits while "doing good" by meeting the needs of minorities, adults, and first-generation college students. ${ }^{37}$

The profit-seeking motive of proprietary schools remains problematic for many academics in traditional institutions. For-profit institutions must show a profit to please their stakeholders or stockholders. By this measure, most large 
higher education companies are succeeding quite well: their revenue has grown "to $\$ 26$ billion in the past decade." ${ }^{38}$

How do they do this? Proprietary schools offer only the essentials of a postsecondary degree, thus allowing them to shed many of the expensive trappings of a traditional college or university. According to Berg, " $[\mathrm{m}] \mathrm{uch}$ of the cost-effectiveness of these institutions comes at the expense of faculty members through lower compensation rates, lack of tenure, and less influence on the management of the university." ${ }^{39}$ Most faculty members at the for-profits are part-time and at-will employees, hired to teach from term to term in the absence of a promotion-and-tenure system. As such, they typically have little or no role in academic governance; we rarely came across a faculty senate-type of structure.

Many larger institutions awarding advanced degrees do expect their faculty to conduct some scholarly research. Nevertheless, for most proprietary schools, the emphasis is on teaching, and many of their faculty members seem content to be relieved of the necessity for research and publication. We found that, in most Ohio career schools, the faculty teaching load is far heavier (for instance, reaching 30 contact hours a week) than at traditional institutions. On the other hand, class size, especially in face-to-face courses, is often small (frequently with fewer than 10 students), and faculty members have few commitments, such as committee responsibilities, other than teaching. The Ohio reviews revealed frequent shortcomings in academic credentials of faculty members at the career schools. ${ }^{40}$

Curriculum development costs are streamlined in the for-profit sector. Curricula in larger institutions are usually designed by subject matter specialists for a national audience and are standardized among the various campuses. They focus on specialized courses relating to the programs offered and on hands-on learning. In recent years - often in response to accreditation requirements-proprietary schools have added general education courses and developmental courses for students with deficiencies in writing or math. Faculty members typically participate little in the development of the curriculum and have a modest role, if any, in making curricular changes. In larger online proprietary institutions where content is delivered via a standardized format, instructors hired to conduct the class cannot independently change the goals, content, assessment tools, or assignments. Rather, their role is largely to grade assignments, answer questions, and provide feedback for the discussion groups.

Proprietary schools appear to excel at student support services that are "engineered to move students through the program successfully," ${ }^{41}$ and they may surpass those of community colleges in retention and career placement. Traditional student services such as psychosocial counseling, extracurricular activities, or health centers, however, are absent or minimal at most for-profit institutions. Occasionally for-profits sponsor student associations, but they consider social organizations and sports teams unnecessary. Indeed, their students have little time for or interest in these types of extracurricular activities.

Other expenses kept to a minimum at proprietary schools include their physical facilities. Although appropriate for teaching classes, the campuses lack spacious grounds that incur maintenance costs. They rarely have dormitories, athletic facilities, student unions, or library buildings.

As for revenues, almost 95 percent of proprietary school income comes from student tuition fees. ${ }^{42}$ Tuition rates are high: “... an average of $\$ 14,174$ this year, compared with $\$ 2,544$ at public two-year institutions and $\$ 7,020$ for in-state tuition at public four-year institutions." ${ }^{43}$ Proprietary schools generally do not have endowments or direct public subsidies.

Nevertheless, indirect public subsidies, particularly federal aid to students, are substantial. "Charges and countercharges about the appropriateness of private 
career schools' participation in federal student aid programs lie at the heart of today's increasing interest in the sector." ${ }^{44}$ To pay for the high tuition fees, most proprietary school students must borrow money, often the entire amount needed to complete a degree. To this end, proprietary schools have turned to federal student loan opportunities for their students. Data on Pell Grants reveal that, in 2008-2009, proprietary schools topped the list of postsecondary institutions receiving aid. "Pell Grant recipients make up about 50 percent of enrollment at proprietary institutions, a larger share than at other types of colleges. Among degree-granting institutions, proprietary colleges represented about 6 percent of all undergraduates but about 20 percent of all those students receiving Pell Grants." ${ }^{45}$

Regional accreditation, the standard for traditional institutions, is coveted by proprietary schools. BusinessWeek reported on the recent acquisitions by large, for-profit corporations of small, struggling colleges that already have regional accreditation. ${ }^{46}$ The existing facilities and faculty may not be retained, but the for-profit buyer has acquired regional accreditation status, thereby bypassing the normal five-year period of application and review. This practice recently received a major setback when the Higher Learning Commission refused to extend accreditation to a group of investors seeking to purchase Dana College, which has resulted in the closing of this 126-year-old Nebraska institution. ${ }^{47}$

Government aid is largely in the form of direct loans to students, and these loans must be repaid. The high levels of debt incurred by students at the for-profits make them particularly susceptible to defaulting on federal loans. A recent article describes the plight of a for-profit student who "is nearly $\$ 100,000$ in debt with no degree." ${ }^{48}$ Given their debt load, it is not surprising that students at for-profit institutions constitute 44 percent of those now defaulting on federal student loans. ${ }^{49}$

Another problematic issue for proprietary schools is that of nontransferability of course credit. Typically, coursework taken at career schools without regional accreditation is not transferable to community colleges or to traditional four-year schools. Students may find employment in the short term but are often surprised to learn later-when contemplating going on for an advanced degree-that their credits will not be accepted by not-forprofit institutions. Although nontransferability statements are usually published in college catalogs and other materials, the authors found that students often do not understand their significance.

Just as at traditional institutions, the quality of education at proprietary schools varies. Some programs and faculty are strong, and a motivated student is able to receive a solid education that leads to a professional career. At other schools, the standards seem suspiciously low, casting doubt on the creditability of the programs. In addition, some institutions allow admission of academically deficient students and issue statements promising that the student will not have to take "fluff" courses (remedial reading, writing, mathematics). The authors saw that, because of this inadequate student preparation, some classes were pitched at a lower level than most traditional colleges would deem acceptable. As a result, some students may never develop reading, writing, and mathematical skills adequate for competing in the marketplace, even after obtaining a career school degree.

The role and effect of public policy on the for-profits has been examined by several authors. Both their successes and their shortcomings have brought proprietary schools under the scrutiny of the federal government: "[a] sea change came to proprietary schools in the early 1990s, when scandals concerning recruiting, loan default rates, and poor educational outcomes (e.g., completion rates) led to tougher federal standards for schools that wanted to participate in Title IV federal student loan assistance." ${ }^{50}$ Among these tightened restrictions were stricter accreditation standards: a new 
law may prevent new for-profits from obtaining federal financial aid for two years. Although federal law dictates that, to participate in the student aid program, 10 percent of a proprietary school's revenue must come from sources other than federal student loans, the impact of this law was considerably weakened in 2008 under the Bush administration.

In 2010, the Obama administration proposed tightening oversight of federal student aid. "Starting in 2014, schools with loan default rates that top 30 percent for three years or 40 percent for one year can lose access to federal aid." ${ }^{51}$ As of this writing, the Administration proposes eliminating loopholes in the banning of compensation for admissions recruiters on the basis of enrollment numbers. Also proposed are policy changes requiring for-profits to disclose their job placement rates, requiring vocational schools receiving federal aid dollars to ensure their students are prepared for "gainful employment," 52 and imposing penalties upon for-profit schools whose students graduate with a debt-to-earnings ratio that is too high. ${ }^{53}$ Given the intensive lobbying efforts of the for-profit institutions, it remains to be seen which new policies will actually be implemented.

\section{Concerns about Libraries in For- Profit Schools}

From the authors' participation in the Ohio Board of Regents' reviews of forprofit schools, we learned from direct experience how their libraries fared against the standards of the library profession. Our insights are further informed by assessment experiences at for-profit institutions outside Ohio, as well as discussions with colleagues who are fellow evaluators. The characteristics of libraries of for-profit institutions in other states may vary, depending on state and regional accreditation standards and other factors.

In Ohio, the schools reviewed ranged from small schools that were literally "mom-and-pop" colleges to national, corporate-run education providers. Par- ticularly in some of the larger systems the authors visited, we did find libraries with admirable resources and services, staffed by qualified professionals who enjoy solid administrative support. Nevertheless, most career school libraries in Ohio are small compared with those in nonprofit institutions of similar enrollments and programs, and the for-profits generally kept library expenditures at a modest level. This discussion focuses primarily on the shortcomings found at the smaller career colleges in Ohio. They can be boiled down to three basic questions that will be familiar to all librarians.

\section{What is a library?}

Lack of understanding of the purpose of an academic library. Often because the administration itself lacked experience with academic libraries, there was little awareness of what today's library is able to contribute to the academic mission. Too often, a library meant the provision of a few "packaged" digital resources, with no thought given to the instructional role of a librarian or to services that can directly support teaching and learning.

Lack of a library advocate in the organization. At traditional institutions, the library usually reports to the chief academic officer. In a large corporate structure, national decision makers located at a distant headquarters typically did not include a spokesperson for the library. At smaller career schools, the flattened hierarchy also meant insufficient library representation in academic decision making. As a result, the library was not integrated into academic processes, lacking a strategic plan or assessment measures aligned with institutional goals. The library budget was usually limited, particularly when compared with traditional institutions of similar size and degree-granting levels. Often the driving force behind attaining certain levels of library resources was the accreditation requirements of professions such as health sciences.

Lack of an appropriately credentialed librarian. Some career schools had no li- 
brarian on the staff or had only a part-time professional. Even when an institution had a librarian, its administrators typically had little awareness of the differences in education and experience of a public, school, and academic librarian. Many believed a librarian of any background could step into the position without additional education or training. With little understanding of a library education, they did not value the position of librarian.

The small size of some of the libraries in career schools may lead to the erroneous notion that their librarian would have little to do. On the contrary, a one-person library requires the librarian to assume a considerable amount of responsibility in all operational areas. Where part-time librarians were present, their limited hours allowed them only to set up basic services such as compiling a collection inventory or overseeing circulation. Librarians were usually overlooked as part of the instructional team, and we rarely saw an "embedded librarian" in for-profit schools.

The national providers with four-year programs usually had appropriately credentialed librarians with relevant experience who were valued members of the curriculum/instructional team. Sometimes, however, a librarian was present only on those campuses where state regulations required it. Other models of library service included formal agreements with a traditional university (example: Kaplan's reliance on the University of Alabama at Huntsville to provide interlibrary loan for Kaplan students). The libraries of Johns Hopkins University and Indiana University have also engaged in feefor-service agreements with proprietary schools that included a mix of reference service, collection management, vendor negotiations, and Web site design. Nevertheless, the authors found the levels of library service and librarian involvement at most for-profit schools visited were lower than at most traditional nonprofits.

Not understanding the differences between a public library and an academic library. The administration of one career school without a librarian had assigned the library to an existing staff member and sent that person to the town's public library to learn how to run a library. Too often, when the authors inquired about additional library resources, the institution referred to the circulation privileges their students had with nearby public libraries. Although some of those libraries were part of large municipal systems, they did not necessarily have the facilities, staff, or collections to support the demands of students from the for-profit schools. In these cases, there was often no evidence that the public library staff was aware of the career school's expectations, and usually no formal written agreement existed between the forprofit and the public library. For example, no provision was made for instructing students of the for-profit institution in the use of relevant resources to complete course assignments successfully.

Lack of space. At Ohio's career colleges, the school was typically contained in a single building, and the library was usually located in one room. The space could not house an adequate collection or sufficient study areas. When a library did have enough space to hold tables and chairs, it was not uncommon for the administration to assign other uses for that space (such as standardized testing). The larger for-profit universities did have physical libraries. Most national providers, however, simply leased space in buildings located off major highways for convenience of access. These rooms were usually classroom space; rarely was there a full library.

Limited use of Web site. At most proprietary schools, the purpose of the institution's Web site is to funnel prospective students to an admissions representative. Except at larger schools, the institutional Web site rarely mentions the library. Content is centrally controlled, with standardized sites for all campuses. Typically librarians cannot add links to library information on either its Web site or a student portal without permission, sometimes from a national office. Some 
enterprising librarians use free services to host a library homepage or an online catalog, resulting in a confusing amalgam instead of a single, institution-hosted site.

\section{Isn't everything online?}

Overreliance on electronic resources. We found that the administrators at for-profit schools usually thought about the library solely in terms of its collections. Especially at the smaller career schools, they were satisfied with a few inexpensive and readily available databases, rather than selecting databases that matched curricular needs. Print book and periodical collections were quite modest.

Inadequate bibliographic control. Despite the emphasis on collections, administrators often overlooked the ease of access to and use of these resources. We found little understanding that electronic resources must be organized to be useful for students. The smaller career colleges in particular had only rudimentary tools for bibliographic control, sometimes consisting of an author-title printout of the holdings. Without resources to participate in established networks such as OCLC, librarians at some career schools have successfully used free tools at their disposal (such as LibraryThing) as the library's catalog.

Lack of standard services. As reviewers, we quickly learned not to assume that a small career school library would offer the services considered standard in a traditional academic library. We found that both students and faculty members at some institutions had restricted circulation access to the library's print materials. At one career school, library materials did not circulate at all. Even in the few libraries that did offer interlibrary loan services, they were often not publicized. At for-profits without a librarian on staff, professional-level reference services were unavailable.

Library services should encompass ways to make the library easier to use. Although we did find printed handouts (for example, directions for database log-ins) at the career schools, we seldom encountered appropriate gateways to databases that included online instructions or help for users in selecting the best database for their needs.

The lack of substantive instruction in information literacy was the area of greatest deficiency in all the for-profit schools we reviewed, regardless of size. Often institutional staff members were unclear about the meaning of the term "information literacy" and thought that library orientation sessions sufficiently addressed library instructional needs.

\section{Who needs a library?}

Lack of demand on the part of students and faculty. According to administrators at the Ohio career schools, the lack of student and faculty buy-in was among their top library challenges. ${ }^{54}$ It was not surprising that career school students generally showed little interest in using the library. Even at traditional institutions, most library use is curriculumdriven: unless students are required to use library resources, few take the initiative to do so. The students at the career schools we visited were similar to student populations at for-profits throughout the country: many came from disadvantaged backgrounds, worked full-time, and often were single mothers. The demands of these external factors made students reluctant or even unable to spend time in the library outside of class.

Because many faculty members at the Ohio career schools were part-time and often temporary, their time and interest in building up library resources were limited. In addition, they probably were not aware of the types of library resources available. Faced with uncertainty and sometimes student resistance, many likely found it easier to avoid assignments that require library use, a situation not unknown among traditional institutions.

Particularly at schools offering only two-year degrees, expectations for faculty scholarship were limited, if they existed at all. Professional development activities were largely in-service training sessions in pedagogy, so there was no need for li- 
brary resources to support research. Even to support their teaching and learning activities, we found these faculty members and students lacked familiarity with what a library and librarian can offer.

Lack of curricular needs for a library. Just as the curriculum was usually prescribed at a proprietary school, so were the library resources to support it. Course assignments were mostly geared to what is readily available: at one for-profit university, for example, course syllabi provided students with links for a number of articles available online and asked them to read a selection of them and write an essay based on their readings. There was little expectation or encouragement of students to read and explore widely.

Lack of interest in lifelong learning. Given the primary focus of these career schools on graduating students who can find employment, little interest existed in the library's role outside of its support for class requirements. Despite occasional lipservice to lifelong learning, little time or effort is expended in developing lifelong learners, even in teaching students how to keep up in a discipline after graduation.

Lack of academic qualifications in leadership. Particularly in larger corporate structures, the president of a campus will often be a businessperson without an advanced degree other than an MBA. Although even at traditional institutions the presidents are increasingly distanced from academics by the need for an increased emphasis on fundraising, most come from an academic background with an appreciation of scholarship and the research process, as well as an understanding of the difference between education and training. This is not the rule for senior managers of the for-profit institutions. In a few instances, the authors found that the local president had management experience but did not hold even a baccalaureate degree, evidence of the values in the for-profit education industry.

\section{How to Address the Library Issues}

We recognize that some of the challenges we describe also exist in the nonprofit sector of higher education (such as the lack of financial support for libraries and lack of understanding of how librarians can support the institutional mission). Nevertheless, we were struck by the extremes encountered in the for-profit sector and saw a need for recommendations to address the issues we identified in the Ohio review process.

Institutional and corporate administrators in a bottom-line-conscious industry need to be convinced that an appropriate level of library services will improve the quality of education and thus deserve the expenses required. Without that cognizance, only the requirements of accrediting agencies or, in our case, the standards of the Ohio Board of Regents, will lead to change in the role of libraries in proprietary schools. Ruch found in his experience that proprietary school "[1]ibraries are basically regarded as an expensive and somewhat marginal utility... Were it not for a clear directive from the North Central Association..., the corporate leadership at DeVry [a national for-profit institution] probably would have been satisfied with smaller libraries." 55

Typically, the recommendations of the Ohio Board of Regents' review teams relating to the library function start with a requirement to hire a qualified librarian - that is, a professional with a graduate degree from an American Library Association-accredited institution. Having a librarian with the appropriate academic library and management experience would resolve many of the issues raised (such as instituting instruction in information literacy). Because many proprietary schools have only a few full-time faculty members, employing a full-time librarian can represent a sizable investment. Nevertheless, the progress reports submitted to the Ohio Board of Regents by the career schools document the often immediate and substantial improvements in library services following the hiring of a librarian. We also heard glowing reports from both faculty members and students about 
the difference that a properly prepared librarian has made in their institution. Anecdotally, we found that librarians, having proven their worth, were subsequently accorded a high degree of respect by administrators and faculty members.

Review teams frequently recommend integrating the library into academic processes such as planning and assessment. Librarians should themselves take the initiative to establish library goals aligned with institutional ones and to collect data that facilitate effective advocacy for the library's, and thus the institution's, goals. Administrators tend to respond to datadriven assessment, particularly at for-profit institutions with an eye on the bottom line.

Broader library issues facing proprietary schools include whether they should be allowed to join statewide resourcesharing consortia. Currently in Ohio, their for-profit status makes them ineligible for membership in OhioLINK, which has dramatically raised the level of resource availability for nonprofit libraries in that state. In some other states, however, the for-profits are eligible to participate in similar consortia, sometimes for a fee. For-profit institutions believe they should be able to share those resources equitably. At the same time, they must recognize the need for payment and the reciprocal expectations of some resource-sharing agreements. The limited size of a career college's own collection often severely restricts its ability to meet minimal requirements for interlibrary loan agreements.

Fees are a significant concern for the for-profits wishing to gain access to certain digital library resources. Because they are considered corporate customers and not educational institutions, proprietary schools may be ineligible for access to some collections (such as ArtSTOR) or may be charged higher licensing fees for them. A librarian recently posted on a listserv the news of a 200 percent increase in database licensing fees charged to her institution because of its for-profit status.

Proprietary schools themselves may not be doing enough to strengthen co- operation among their own libraries. At our library workshop, we discovered that many attendees were meeting their counterparts for the first time, even librarians within the same corporation. Merely an exchange of telephone numbers and email addresses can be an invaluable source of information and support, especially for an individual in a one-person library.

We also recommend that for-profits do more to explore alternatives to acquiring resources. For example, they could investigate and support organizations such as the nonprofit Library and Information Resources Network (LIRN), whose membership is open to any institution willing to pay to join and share in its online database offerings. Members also have the opportunity to help develop LIRN's collections areas.

Libraries at nonprofits have a long history of collaborating with their peers to leverage limited resources for joint purchases and access. We believe libraries of for-profit schools should also investigate the possibilities of joining existing consortia or teaming up with other proprietary schools to create their own consortia for increased leverage with networks and vendors. This level of cooperation may be more challenging among the for-profits, who view each other as direct competitors with whom they may be reluctant to share data and plans.

\section{What For-Profits and Their Libraries Do Well}

The growing enrollment figures at proprietary schools indicate that the for-profits are attracting students even in the face of difficult economic times and despite their high tuition rates. Although some practices of for-profit schools are not without considerable controversy, we describe here what we think these institutions are doing right.

Focusing on the student. Student interviews are always a part of the Regents' reviews, and typically students praise the schools for the personal attention showered upon them. Students like be- 
ing known as individuals by faculty and administrators (including the librarian), and they prize the sense that the staff truly cares about them. Students also enjoy the small class sizes, where they receive more attention. The authors met numerous students who expressed deeply felt appreciation for the opportunities afforded them by their institutions, including receiving a "second chance" at higher education.

A frequent responsibility of faculty members at a career school is to follow up via phone or e-mail with every student who misses a class. They are required to document those follow-up actions, which become part of the record for their performance appraisals. No doubt some of this is influenced by the bottom-line orientation of the for-profits (in other words, students who drop out do not pay tuition). Nevertheless, the authors met numerous faculty members and administrators who derived considerable satisfaction from helping disadvantaged students to complete their education at their for-profit institutions. Certainly many individual faculty members at nonprofit schools give individual attention to students, but seldom is the policy of individual attention as "institutionalized" as the authors have seen at the for-profits. Often the sheer numbers of students at larger institutions, including community colleges, preclude such individual attention, but at what loss to both the individual and to society?

The for-profits also apply their strong customer orientation to shape academic programs to the needs of the student. For example, terms of study are frequently compacted so a student can finish a program in one-and-a-half years instead of two, and classes may be offered entirely in the evenings so working adults can attend them. Classes might start every two or three weeks, so a student does not need to wait a semester or a year to take a required course. The institution is flexible in accommodating students who need to alter their schedules temporarily or who have to drop out and re-register. Meanwhile, most nonprofit institutions maintain traditional schedules and lengths of times to complete programs and degrees, without clear evidence of their educational and personal benefits.

Career services. Because their focus is on employment for their graduates, proprietary schools place great emphasis on career guidance, which begins very early and not only as the student approaches graduation. Even the smallest school assigns a full-time staff member to Career Services. A key statistic tracked by career schools is job placement rate, and most report a high percentage (although not all students may be placed in a job that makes use of their recently earned degree). These schools routinely use program advisory committees, composed of potential employers and other members of the external community, to give them practical advice on the kinds of skills and knowledge needed in their new hires.

Responsiveness to needed teaching improvement. Without tenure-based requirements in for-profits, proprietary institutions are able to act easily and quickly when poor teaching performance is documented. Often the response is to provide more pedagogical training, but if improvement does not occur, an at-will faculty member will find his or her contract is not renewed for the next term. Such prompt action would be most unusual at a traditional institution with a tenured, and possibly unionized, faculty. Although faculty members need both job security and protection of intellectual freedom, students also need protection from incompetent teachers, and most for-profits have found a way to deal with the issue relatively quickly.

Using tools from the business world. Many traditional educational institutions have been slower to implement tools that the proprietary schools have applied with success toward their profit-making goals. For example, most of the larger for-profits make effective use of strategic planning as a tool for improving their operations, perhaps because their bottom-line orientation provides a readily measurable goal. They also make good use of needs assessments 
to enhance their responsiveness to market forces. They develop and implement new programs quickly. This agility is often in marked contrast to the slow processes of curriculum and program review at most nonprofit institutions, where the elimination of programs and the addition of new ones may take months or years.

Proprietary schools are willing to invest significant resources in marketing. In a single quarter, for example, one higher education company spent 20 percent of its total net revenue for the quarter on marketing. ${ }^{56}$

Use of public libraries. Although the abuse of reliance on public libraries has been mentioned, some career school libraries make appropriate use of the public library as a supplemental resource and not as a replacement for its own library. For example, some schools organize field trips to the local public library or arrange to issue public library cards, especially useful since the typical student might be a single mother with no previous library experience and no home computer. Where a for-profit institution has established good communications with the local public library, the arrangements can work well for all involved.

\section{Conclusions}

The authors' experience with the Ohio Board of Regents' reviews of for-profit schools found some large systems had appropriate libraries, but the majority of career schools had libraries that were inadequate. In general, these libraries lack the foundational support accorded to libraries at traditional, nonprofit institutions and, therefore, trail them in both the scope and quality of their library services. This finding does not mean, however, that the situation is acceptable or that librarians at the for-profits cannot prove the worth of their services and collections to their parent institutions. We did find evidence of hardworking, well-qualified librarians working creatively and successfully with faculty members, students, and administrators to position the library in a more central role at their institutions.
While we have offered several specific recommendations to address our concerns, the most critical is the employment of a qualified librarian. This hire is necessary if proprietary schools are to provide the level of education expected of them, not only by accreditors but also increasingly by their students and the general public.

In the absence of substantive research on this sector of librarianship, the field is wide open for library scholars. Questions awaiting study range from what changes occur after the hiring of a professional librarian, to how proprietary school librarians can best earn faculty acceptance of their role in instruction, to examples of information literacy efforts in the for-profits. Even the collection of basic comparative data among career school libraries would be a useful addition to the literature. Potential researchers should be aware of factors specific to this sector; for example, their for-profit nature may pose a barrier to certain areas of research involving financial data that are considered confidential.

For-profits that operate with high educational and ethical standards appear to be filling a legitimate niche, judged by their increasing enrollments. Their focus on students and effective use of business practices have resulted in schools with programs and procedures that appeal to many. Still unresolved, however, are several issues. How candid and honest are the for-profits in recruiting their students? Should large corporations be making huge profit margins by offering an education to individuals who may lack the opportunities and abilities to obtain it elsewhere? Is it acceptable that the federal and state governments underwrite (via student aid monies) this education and those who profit from it? Or would society be better served if federal and state governments channeled these student aid funds toward the provision of more support for nonprofit community and vocational schools and to the regionally accredited nonprofit institutions?

Whatever the answers, it is worth noting Watson Scott Swail's caution that 
"[t]he education community cannot and should not ignore this sector of higher education, because it will play an increasingly important role in our nation's ability to retool and prepare for increased competition from Asia and other areas." ${ }^{57}$
Academic librarians in nonprofit institutions would do equally well not to ignore their colleagues in the for-profit sector but should assist them in achieving and sustaining the standards we have come to expect of our profession.

\section{Notes}

1. Robin Wilson, “For-Profit Colleges Change Higher Education's Landscape: Nimble Companies Gain a Fast-Growing Share of Enrollments," The Chronicle of Higher Education, Feb. 7, 2010, available online at http://chronicle.com/article/For-Profit-Colleges-Change-/64012/ [accessed 16 July 2010].

2. David L. Kirp, "Education for Profit," Currents in Higher Education (Summer 2003): 100-12.

3. The authors assessed the library function in proprietary institutions against the Association of College and Research Libraries' "Standards for Libraries in Higher Education" (approved June 2004), which is applicable to all types of academic libraries. To aid the career schools, we developed the document (also based on the ACRL standards) "Guidelines for Libraries in Career Schools" for the Ohio Board of Regents.

4. John B. Lee and Jamie P. Merisotis, "Proprietary Schools: Programs, Policies and Prospects," ASHE-ERIC Higher Education Report, no. 5 (Washington, D.C.: George Washington University, School of Education and Human Development, 1990).

5. Eboni M. Zamani-Gallaher, "Proprietary Schools: Beyond the Issue of Profit," New Directions for Institutional Research no. 124 (Winter 2004): 63-79.

6. Richard S. Ruch, Higher Ed, Inc.: The Rise of the For-Profit University (Baltimore: Johns Hopkins University Press, 2001).

7. Gary A. Berg, Lessons from the Edge: For-Profit and Nontraditional Higher Education in America (Westport, Conn.: Praeger, 2005).

8. Earnings from Learning: The Rise of For-Profit Universities, eds. David W. Breneman, Brian Pusser, and Sarah E. Turner (Albany, N.Y.: State University of New York Press, 2006).

9. Frank Donoghue, The Last Professors; The Corporate University and the Fate of the Humanities (New York: Fordham University Press, 2008).

10 Community Colleges and Proprietary Schools: Conflict or Convergence? New Directions for Community Colleges, no. 91, eds. Darrel A. Clowes and Elizabeth M. Hawthorne (San Francisco: Jossey-Bass, 1995).

11. Thomas Bailey, Norena Badway, and Patricia J. Gumport, "For-Profit Higher Education and Community Colleges," (Stanford, Calif.: National Center for Postsecondary Improvement, 2001).

12. Charles L. Outcalt and James E. Schirmer, "ERIC Review: Understanding the Relationships between Proprietary Schools and Community Colleges: Findings from Recent Literature," Community College Review 31 (Summer 2003), available online at http://findarticles.com/p/articles/ mi_m0HCZ/is_1_31/ai_107200756/ [accessed 16 July 2010].

13. Lee and Merisotis, "Proprietary Schools," iv.

14. Kevin Kinser, "Access in U.S. Higher Education: What Does the For-Profit Sector Contribute?" PROPHE Working Paper Series, WP no. 14 (Albany, N.Y.: University at Albany, State University of New York, 2009), 18.

15. Watson Scott Swail, Graduating At-Risk Students: A Cross-Section Analysis (Washington, D.C.: Imagine America Foundation, 2009).

16. Jennifer Gonzalez, "Study Points to Academic Success of Students Attending For-Profit Colleges," The Chronicle of Higher Education, Jan. 27, 2010, available online at http://chronicle.com/ article/Study-Points-to-Academic/63760/ttp://findarticles.com/p/articles/mi_m0HCZ/is_1_31/ ai_107200756/ [accessed 16 July 2010].

17. Ruch, Higher Ed, Inc., 6-7.

18. Peter S. Goodman, "In Hard Times, Lured into Trade School and Debt," New York Times, Mar. 13, 2010, available online at www.nytimes.com/2010/03/14/business/14schools.html [accessed 16 July 2010].

19. Zamani-Gallaher, "Proprietary Schools," 73.

20. Kinser, "Access in U.S. Higher Education," 17.

21. Ibid., 1 .

22. See, for example, Lucy Lee's "Community Colleges and Proprietary Schools" (ERIC Identifier ED400003, 1996), available online at www.ericdigests.org/1997-2/colleges.htm [accessed 16 July 2010]. 
23. Kinser, "Access in U.S. Higher Education," 19.

24. Ruch, Higher Ed, Inc., 96.

25. Kirp, "Education for Profit," 111.

26. For more information about the rise of the for-profits in the context of higher education in the United States, see, for example, Breneman, Pusser, and Turner's Earnings from Learning or Donoghue's The Last Professors.

27. Ruch, Higher Ed, Inc., 52.

28. Zamani-Gallaher, "Proprietary Schools," 64.

29. Lee and Merisotis, "Proprietary Schools," iii.

30. Note that the term "career schools" is frequently used to refer to the entire for-profit sector. Usually, however, it carries a connotation of the narrower scope of two-year institutions in the second category.

31. Wilson, "For-Profit Colleges."

32. Doug Lederman, "For-Profit Colleges Boom," Inside Higher Ed, Apr. 7, 2010, available online at www.insidehighered.com/news/2010/04/07/enroll [accessed 16 July 2010].

33. Wilson, "For-Profit Colleges."

34 Outcalt and Schirmer, "ERIC Review: Understanding the Relationship."

35. Daniel de Vise, "Report Finds Fraud in For-profit Education Firms' Recruiting," Washington Post, Aug. 4, 2010, available online at www.washingtonpost.com/wp-dyn/content/article/2010/08/03/AR2010080303846.html [accessed 4 August 2010].

36. Swail, Graduating At-Risk Students, 14.

37. Gary Berg, "Reform Higher Education with Capitalism? Doing Good and Making Money at the For-Profit Universities," Change 37 (May 2005), available online at http://www.jstor.org/ pss/40178167 [accessed 15 September 2011].

38. Daniel Golden, "Your Taxes Support For-Profits as They Buy Colleges (Update 3)," BusinessWeek, Mar. 8, 2010, available online at http://www.businessweek.com/news/2010-03-04/ your-taxes-supporting-for-profit-firms-as-they-acquire-colleges.html [accessed 16 July 2010].

39. Berg, "Reform Higher Education."

40. This statement refers to faculty credentials as assessed against the Ohio Board of Regents' standards, which generally require faculty members to hold a degree one level higher than the program in which they are teaching.

41. Outcalt and Schirmer, "ERIC Review."

42. Ruch, Higher Ed, Inc., 97.

43. Wilson, "For-Profit Colleges."

44. Lee and Merisotis, "Proprietary Schools," iii.

45. "For-Profit Colleges Capitalize on Pell Grant Revenue," The Chronicle of Higher Education, Financial Data, Data Points, Jan. 4, 2010, available online at http://chronicle.com/article/DataPoints-For-Profit/63388 [accessed 16 July 2010].

46. Golden, "Your Taxes Support For-Profits."

47 Timberly Ross, "Future of Dana College Campus Unknown," Lincoln Journal Star, July 12, 2010, available online at http://journalstar.com/news/state-and-regional/nebraska/article_1a66dfec8df3-11df-b4c6-001cc4c002e0.html [accessed 16 July 2010].

48. Susan Snyder, "For-Profit Colleges Leave Many Students in Debt." Philadelphia Inquirer, May 6, 2010, available online at http://www.philly.com/philly/news/local/20100506\%29Forprofit_colleges_leave_many_students_in_debt.html [accessed 3 June 2010].

49. "New Default Rate Data for Federal Student Loans: $44 \%$ of Defaulters Attended For-Profit Institutions," Dec. 15, 2009, available online at http://www.pewtrusts.org/news_room_detail. aspx?id=56473 [accessed 16 July 2010].

50. Outcalt and Schirmer, "ERIC Review."

51. Dick Durbin, "For-Profit Colleges and Federal Student Aid: Preventing Financial Abuses," June 30, 2010, available online at http://durbin.senate.gov/showRelease.cfm?releaseId=326085 [accessed 31 July 2010].

52. Ibid.

53. Jennifer Epstein, "Splitting the Difference on Gainful Employment," Inside Higher Education, July 23, 2010, available online at http://www.insidehighered.com/layout/set/print/news/2010/07/23/ gainful [accessed 31 July 2010].

54. In 2009, the authors conducted an Ohio Board of Regents workshop for librarians at career schools and for the administrators to whom they report. The administrators stated that, after the hiring of a librarian, the lack of student and faculty buy-in and the lack of library space were the most significant challenges facing their libraries.

55. Ruch, Higher Ed, Inc., 41.

56. Wilson, "For-Profit Colleges."

57. Gonzalez, "Study Points to Academic Success." 